\title{
PENGARUH MOTIVASI DAN MENTAL BERWIRAUSAHA TERHADAP MINAT BERWIRAUSAHA MAHASISWA
}

\author{
Oleh: \\ Anik Ariyanti \\ Sekolah Tinggi Ilmu Ekonomi IPWI Jakarta \\ ariyanti.anik@yahoo.co.id
}

\begin{abstract}
ABSTRAK
Tujuan penelitian ini adalah mengetahui pengaruh motivasi dan mental berwirausaha terhadap minat berwirausaha mahasiswa Program Studi S1 Manajemen STIE IPWI Jakarta. Objek pada penelitian ini adalah mahasiswa Program Studi S1 Manajemen STIE IPWI Jakarta angkatan 20142015 yang mayoritas sudah pernah menempuh mata kuliah Kewirausahaan.

Penelitian ini mengunakan pengumpulan data primer dan sekunder. Sampel yang digunakan dalam penelitian ini sejumlah 40 mahasiswa dari jumlah populasi 200 mahasiwa. Data dioleh dengan menggunakan SPSS 16 dan diuji dengan uji validitas, reliabilitas, uji asumsi klasik, uji regresi ganda, uji uji hipotesis dan uji koefisien determinasi.

Hasil penelitian menunjukkan bahwa motivasi berwirausaha berpengaruh positif dan signifikan terhadap minat berwirausaha, mental berwirausaha berpengaruh positif dan signifikan terhadap minat berwirausaha dan secara simultan motivasi berwirausaha dan mental berwirausaha berpengaruh positif dan signifikan terhadap minat berwirausaha para mahasiswa Program Studi S1 Manajemen STIE IPWI Jakarta.
\end{abstract}

Kata kunci:

Motivasi berwirausaha, mental berwirausaha dan minat berwirausaha

\section{PENDAHULUAN}

Saat ini di era globalisasi, kewirausahaan (enterpreneur) merupakan persoalan yang sangat penting untuk meningkatkan perekonomian negara. Kemajuan dan kemunduran ekonomi suatu bangsa sangat ditentukan oleh keberadaan para wirausahawan. Perkembangan kewirausahaan di Indonesia saat ini masih sangat rendah jika dibandingkan dengan negara-negara Asia lainnya. Di negara-negara maju di Benua Eropa maupun Amerika, setiap sepuluh menit lahir wirausahawan baru.
Pertumbuhan ini membawa peningkatan perekonomian luar biasa bagi suatu negara. Menurut Mc. Clelland, suatu Negara bisa menjadi makmur apabila ada terdapat enterpreneur sedikitnya $2 \%$ dari jumlah penduduk yang ada. Kewirausahaan adalah proses dimana seorang individu atau kelompok individu menggunakan upaya terorganisir dan sarana untuk mencari peluang untuk menciptakan nilai dan tumbuh dengan memenuhi keinginan dan kebutuhan melalui inovasi dan keunikan, tidak peduli apa sumber daya yang saat ini 
dikendalikan (Robbin \& Coulter. 2007). Kasmir (2012) menyebutkan bahwa wirausaha adalah orang yang berjiwa berani mengambil resiko untuk membuka usaha dalam berbagai kesempatan. Berjiwa berani mengambil resiko artinya bermental mandiri dan berani memulai usaha, tanpa diliputi oleh rasa takut atau cemas sekalipun dalam kondisi tidak pasti.

Langkah strategis yang dibutuhkan saat ini adalah bagaimana mencetak para generasi muda untuk menjadi wirausaha yang handal. Upaya yang dilakukan haruslah mengarah pada pendidikan kewirausahaan dengan memberikan dorongan dan motivasi untuk menumbuhkan mental berwirausaha pada para generasi muda agar mempunyai minat yang kuat untuk berwirausaha. Penumbuhkembangan motivasi berwirausaha dalam perguruan tinggi menjanjikan harapan yang cerah bagi terciptanya sumber daya manusia yang mandiri dalam berfikir dan bertindak. Mampu menerapkan ilmu yang dipahaminya untuk kesejahteraan diri dan masyarakat. Peran penting perguruan tinggi salah satunya adalah dengan memberikan mata kuliah kewirausahaan yang bertujuan agar lulusan perguruan tinggi tidak bingung dan canggung terjun ke masyarakat, dan motivasi yang tinggi untuk berwirausaha. STIE IPWI Jakarta ikut ambil bagian dalam upaya peningkatan minat berwirausaha pada para mahasiswanya. Hal ini terbukti adanya mata kuliah kewirausahaan yang wajib diikuti oleh para mahasiswa Program Studi S1 Manajemen STIE IPWI Jakarta. Tujuan utama STIE IPWI Jakarta adalah memberikan bekal ilmu pengetahuan kewirausahaan untuk mencetak wirausahawan-wirausahawan yang kreatif dan inovatif.

Ketertarikan mahasiswa terhadap kewirausahaan tidak lepas dari pengaruhnya dari minat yang tumbuh dalam dirinya. Minat adalah sumber motivasi yang mendorong seseorang untuk melakukan apa saja yang ingin dilakukan ketika bebas memilih. Minat tidak bersifat permanen namun bersifat sementara atau dapat berubah-ubah. Minat dalam berwirausaha harus ditumbuhkan sejak dini pada mahasiswa. Minat merupakan kecenderungan perasaan memperhatikan serta menyukai beberapa hal atau kegiatan, minat terhadap sesuatu dipelajari terlebih dahulu dan mempengaruhi belajar selanjutnya, mempengaruhi minat-minat selanjutnya. Membentuk keberanian dalam aspek lain yang didorong oleh pendidik di lembaga pendidikan yang memberikan mata pelajaran yang praktis dan menarik dapat membangkitkan minat peserta didik untuk berwirausaha.

\section{TUJUAN PENELITIAN}

Tujuan dari penelitian ini adalah:

a. Untuk mengetahui pengaruh motivasi berwirausaha terhadap minat berwirausaha mahasiswa STIE IPWI Jakarta.

b. Untuk mengetahui pengaruh mental berwirausaha terhadap minat berwirausaha mahasiswa STIE IPWI Jakarta.

c. Untuk mengetahui pengaruh motivasi berwirausaha dan mental berwirausaha terhadap minat berwirausaha mahasiswa STIE IPWI Jakarta.

\section{TELAAH LITERATUR DAN PENGEMBANGAN HIPOTESIS \\ Motivasi Berwirausaha}

Secara umum motivasi adalah suatu proses yang mendorong atau mempengaruhi seseorang untuk mendapatkan atau mencapai apa yang 
diinginkannya baik itu secara positif maupun negatif. Motivasi akan memberikan perubahan pada seseorang yang muncul akibat dari perasaan, jiwa dan emosi sehingga mendorong untuk melakukan tindakan sesuatu yang disebabkan karena kebutuhan, keinginan dan tujuan tersebut. Motivasi menjadi suatu kekuatan, tenaga atau daya, atau suatu keadaan yang kompleks dan kesiapsediaan dalam diri individu untuk bergerak ke arah tujuan tertentu, baik disadari maupun tidak disadari (Makmun, 2003). Motivasi dipengaruhi oleh faktor internal/instrinsik dan faktor eksternal/ekstrinsik. Motivasi intrinsik adalah motivasi yang bersumber factorfaktor dalam diri sendiri. Faktor intrinsik meliputi dorongan, keinginan diri sendiri untuk mengetahui informasi dan pemahaman, pendapat ketrampilan tertentu, mengembangkan sikap, menikmati kehidupan dan lain-lain. Sedangkan motivasi ekstrinsik adalah bentuk motivasi yang bersumber dari luar diri individu yang sulit dikendalikan dan dapat cepat hilang karena dipengaruhi oleh ajakan orang lain. Elliot et al. (2000), mencontohkannya dengan nilai, hadiah, dan/atau penghargaan yang digunakan untuk merangsang motivasi seseorang.

Kewirausahaan adalah usaha untuk menciptakan nilai melalui pengenalan kesempatan bisnis, manajemen pengambilan resiko yang tepat, dan melalui keterampilan komunikasi dan manajemen untuk memobilisasi manusia, uang, dan bahan-bahan baku atau sumber daya lain yang diperlukan untuk menghasilkan proyek supaya terlaksana dengan baik. (Leonardus Saiman 2014: 41). Sedangkan pengertian kewirausahaan menurut Instruksi Presiden RI No. 4 Tahun 1995 yaitu: "Kewirausahaan adalah semangat, sikap, perilaku, dan kemampuan seseorang dalam menangani usaha dan atau kegiatan yang mengarah pada upaya mencari, menciptakan, menerapkan cara kerja, teknologi, dan produk baru dengan meningkatkan efesiensi dalam rangka memberikan pelayanan yang lebih baik dan atau memperoleh keuntungan yang lebih besar. Berdasarkan penjelasan di atas, dapat kita simpulkan kewirausahaan adalah proses penerapan inovasi dan kreatifitas dalam penemuan peluang usaha yang dilakukan dengan semangat, dan keberanian mengambil resiko.

\section{Mental Berwirausaha}

Secara etimologi kata "mental" berasal dari bahasa Yunani, yang sama dengan pengertian psyche, artinya psikis, jiwa atau kejiwaan. Mental adalah sesuatu yang berhubungan dengan pikiran atau pikiran itu sendiri. Secara sederhana mental dapat dipahami sebagai sesuatu yang berhubungan dengan batin dan watak atau karakter, tidak bersifat jasmani (badan). Mental adalah sesuatu yang ada dalam diri setiap manusia, yang tidak dapat dilihat oleh mata secara langsung, dan keduanya berhubungan dengan kepribadian seseorang.

Mental berwirausaha dapat diartikan sebagai kejiwaan seorang yang pemikirannya selalu berusaha mencari, memanfaatkan, serta menciptakan peluang usaha. Peluang usaha ini mungkin akan menguntungkan baik secara finansial maupun sosial, namun resiko kerugian tak lepas menghantui kita. Tidak ada istilah rugi selama seseorang melakukan usaha dengan penuh keberanian dan penuh perhitungan. Inilah yang disebut jiwa wirausaha. Dan berkemauan keras, keyakinan pada diri, motivasi yang kuat adalah mental wirausaha.

Mental berwirausaha adalah kejiwaan seseorang yang berkemauan keras, keyakinan pada diri, motivasi yang kuat 
adalah mental wirausaha. Dalam menjalankan suatu usaha (wirausaha) seorang pelaku usaha harus memiliki jiwa dan mental yang: 1 . Kreatif dan inovatif; 2. Optimis, tegar dan ulet; 3. Bekerja keras; 4. Multi tasking; 5. Berhemat; dan 6. Berani mengambil resiko. Mental berkaitan erat dengan kepribadian seseorang. Kepribadian merupakan unsur penting sebagai dasar dan titik tolak mencapai hasil dalam perjuangan hidup. Pembinaan mental dan kepribadian dapat dikatakan lebih menitikberatkan membedah pada "tenaga dalam" seperti kejujuran, ketekunan, keuletan, kemauan, tanggung jawab, percaya diri, rajin berdaya upaya, tidak mudah putus asa, tidak mengharap belas kasih dan kreatif.

\section{Minat Berwirausaha}

Minat berhubungan dengan gaya gerak yang mendorong seseorang untuk menghadapi atau berurusah dengan orang, benda, kegiatan, pengalaman yang dirangsang oleh kegiatan itu sendiri $(\mathrm{H}$ Djaali, 2008:121). Minat merupakan kecenderungan pada rasa lebih suka dan rasa ketertarikan pada suatu hal atau aktivitas, tanpa ada paksaan dari luar. Rasa ketertarikan itu bukan karena paksaan tapi kesadaran yang tinggi karena keinginan yang kuat untuk mencapai tujuan. Aspekaspek minat menimbulkan daya ketertarikan yang dibentuk oleh dua aspek yaitu aspek kognitif dan afektif, berupa sikap, kesadaran individual, perasaan senang, arah kepentingan individu, adanya ketertarikan yang muncul dari dalam diri, dan berpartisipasi terhadap apa yang diminati.

Sedangkan minat wirausaha adalah keinginan, ketertarikan serta kesediaan untuk bekerja keras atau berkemauan keras dengan adanya pemusatan perhatian untuk berusaha memenuhi kebutuhan hidupnya tanpa merasa takun akan resiko yang akan dihadapi. Minat berwirausaha meliputi sikap umum terhadap wirausaha, kesadaran spesifik untuk menyukai wirausaha, merasa sendang dengan wirausaha. Untuk menjadi wirausaha yang sukses maka seseorang harus bekerja keras, mempunyai semangat yang tinggi dan yakin terhadap kemampuan dirinya sebagai wirausahawan.

Beberapa faktor yang mempengaruhi minat berwirausaha adalah: a. the factor inner urge adalah rangsangan yang datang dari lingkungan atau ruang lingkup yang sesuai dengan keinginan atau kebutuhan seseorang akan mudah menimbulkan minat, $b$. the factor of social motive adalah minat seseorang terhadap obyek atau sesuatu hal, di samping hal dipengaruhi oleh faktor dari dalam diri manusia juga dipengaruhi oleh motif sosial, dan c. emotional factor adalah faktor perasaan dan emosi mempunyai pengaruh terhadap obyek.

Minat berwirausaha seseorang dapat dilihat dari dua indikator utama yaitu: (1) seberapa kuat upaya seseorang untuk berani mencoba melakukan aktivitas kewirausahaan; (2) seberapa banyak upaya yang direncanakan seseorang untuk melakukan aktivitas kewirausahaan (seperti aktivitas dalam mengelola waktu dan keuangan untuk tujuan berwirausaha). Minat berwirausaha juga dipengaruhi oleh adanya soft skills yang tinggi, karena untuk menjadi seorang wirausahawan dibutuhkan berbagai keterampilan dan karakter pribadi yang kuat.

Aspek kewirausahaan meliputi beberapa hal antara lain: a. mampu menginderakan peluang usaha sehingga mampu melihat dan memanfaatkan peluang untuk mengadakan langkahlangkah perubahan menuju masa depan yang lebih baik, b. memiliki rasa percaya diri dan mampu bersikap positif terhadap diri sendiri dan lingkungannya dan 
berkeyakinan bahwa usaha yang dikelolanya akan berhasil, c. berperilaku memimpin yaitu mengarahkan, menggerakkan orang lain, serta bertanggung jawab untuk meningkatkan usaha, d. memiliki inisiatif untuk jadi kreatif dan inovatif yaitu memiliki prakarsa untuk menciptakan produk atau metode baru lainnya yang lebih baik, mutu dan mampu bersaing, e. mampu bekerja keras secara energik, tekun dan tabah untuk melakukan kegiatan untuk mencapai tujuan tanpa mengenal putus asa, dan $\mathrm{f}$. berpandangan luas dan berani mengambil resiko serta tanggap pada saran dan kritikm sebagai dorongan untuk berbuat lebih baik.

\section{Hipotesis}

H1 : Motivasi berwirausaha berpengaruh positif terhadap minat berwirausaha mahasiswa STIE IPWI Jakarta.

H2 : Mental berwirausaha berpengaruh positif terhadap minat berwirausaha mahasiswa STIE IPWI Jakarta.

H3 : Motivasi berwirausaha dan mental berwirausaha berpengaruh positif terhadap minat berwirausaha mahasiswa STIE IPWI Jakarta

\section{METODE PENELITIAN}

Tempat Penelitian

Penelitian dilakukan di Sekolah Tinggi Ilmu Ekonomi IPWI Jakarta.

\section{Definisi Operasional Motivasi Berwirausaha}

Motivasi berwirausaha adalah suatu yang menggerakan dan mengarahkan seseorang untuk melakukan usaha/kegiatan usaha sebagai upaya untuk mencapai apa yang menjadi keinginannya . Motivasi sebagai bentuk stimulus atau semangat akibat rangsangan atau kegairahan terhadap sesuatu yang benar-benar diingini. Motivasi adalah pemberian daya penggerak yang menciptakan kegairahan kerja seseorang, agar mereka mau bekerja sama, bekerja efektif dan terintegrasi dengan segala daya dan upaya untuk mencapai kepuasan (Hasibuan, 2010: 179).

\section{Mental Berwirausaha}

Mental berwirausaha adalah kemampuan berpikir seorang pengusaha dalam berperilaku dan memiliki tanggung jawab yang besar, disiplin yang tinggi dan inovatif.

\section{Minat Berwirausaha}

Minat berwirausaha adalah sikap dan keinginan yang membuat seseorang tertarik mencoba suatu yang baru dan berusaha untuk memperoleh keuntungan dan mempertimbangkan suatu resiko yang harus dihadapi sehingga menimbulkan kekuatan pendorong kepada individu tersebut untuk menciptakan kesejahteraan bagi individu dan menambah nilai bagi masyarakat dengan mengelola sumber daya yang dimiliki.

\section{Indikator Variabel Penelitian}

Adapun indikator dari masing-masing variabel sebagai berikut:

Tabel 1

Operasionalisasi Instrumen Penelitian

\begin{tabular}{|c|c|c|}
\hline Variabel & Indikator & Skala \\
\hline $\mathrm{X}_{1}$ : Motivasi Berwirausaha & $\begin{array}{l}\text { 1. Dorongan } \\
\text { 2. Penggerak } \\
\text { 3. Stimulus } \\
\text { 4. Semangat } \\
\text { 5. Gairah }\end{array}$ & Likert \\
\hline $\mathrm{X}_{2}$ : Mental Berwirausaha & $\begin{array}{l}\text { 1. Jiwa } \\
\text { 2. Sikap } \\
\text { 3. Positif } \\
\text { 4. Dinamis } \\
\text { 5. Optimis } \\
\end{array}$ & Likert \\
\hline Y: Minat Berwirausaha & $\begin{array}{ll}\text { 1. } & \text { Ketertarikan } \\
\text { 2. } & \text { Kesukaan } \\
\text { 3. } & \text { Kemauan } \\
\text { 4. } & \text { Keinginan } \\
\text { 5. } & \text { Kesediaan }\end{array}$ & Likert \\
\hline
\end{tabular}

Sumber: Kajian Literatur 


\section{Populasi dan Sampel}

a. Populasi

Populasi merupakan wilayah generalisasi yang terdiri dari obyek dan subyek yang memiliki kualitas dan karakteristik tertentu yang dtetapkan peneliti untuk dipelajari dan kemudian ditarik kesimpulannya. Populasi dalam penelitian ini adalah mahasiswa Program Studi S1 Manajemen STIE IPWI Jakarta Angkatan 2014-2015 yang berjumlah 200 orang.

b. Sampel

Sampel adalah bagian dari jumlah dan karateristik yang dimiliki oleh populasi. Menurut Harsimi Arikunto apabila subyek atau populasi kurang dari seratus lebih bai diambil semua sehinggan penelitiannya merupakan penelitian populasi dan jika subyeknya lebih dari seratus maka dapat diambil sampel antara $10-15 \%$ atau $20-25 \%$. Penelitian ini mengambil sampel sebesar 20\% sehingga ditemukan sampel sebesar 40 mahasiswa karena jumlah keseluruhan adalah 200 mahasiswa.

\section{Teknik Pengumpulan Data}

Pengumpulan data merupakan prosedur sistematik dan standard alam menentukan suatu data penelitian. Teknik yang digunakan untuk penelitian ini adalah:

1. Observasi

Observasi ini merupakan metode pengumpulan data yang menggunakan pengamatan terhadap obyek penelitian karena adanya suatu gejala atau gerakan dari obyek penelitian. Observasi digunakan untuk memperoleh data tentang keadaan kampus, tempat belajar dan aktivitas yang ada di kampus STIE
IPWI Jakarta, yang mendukung penelitian.

2. Dokumentasi

Dokumentasi ini adalah pengumpulan data mengenai hal-hal atau variabel berupa catatan yang tertulis seperti buku, surat-surat, foto dan dokumen mengenai gambaran objek penelitian. Dokumentasi ini nantinya akan digunakan untuk mengetahui struktur organisasi STIE, sarana prasarana, keadaan mahasiswa, dosen dan para pegawai serta prestasi belajar mahasiswa, khususnya mata kuliah kewirausahaan.

3. Kuesioner

Kuesioner ini adalah alat untuk mendapatkan data primer penelitian. Kuesioner ini digunakan untuk mencari data tentang motivasi berwirausaha, mental berwirausaha dan minat berwirausaha. Kuesioner yang diperlukan adalah kuesioner tertutup dengan arternatif jawaban telah tersedia, dan responden tinggal memberi tanda pada jawaban yang dipilih sesuai dengan skala Likert.

\section{Uji Validitas dan Reliablitas Instrumen U $j i$ Validitas}

Uji validitas instrument dilakukan untuk menunjukkan keabsahan instrument yang akan dipakai pada penelitian. Alat ukur dikatakan valid jika benar-benar sesuai dan menjawab secara cermat tentang variabelyang akan diukur. Validitas juga menunjukkan sejauh mana ketepatan pernyataan dengan apa yang dinyatakan sesuai dengan koefisien validitas. Pengujian uji validitas ini menggunakan program Statistical Package for the Social Science (SPSS). Langkah selanjutnya adalah mengukur $r$ hitung dengan $r$ tabel dengan tingkat kepercayaan $95 \%$ atau a $=0,1$ dengan $\mathrm{dk}=\mathrm{n}-2(\mathrm{dk}=40$ $3=37$ ). Jika dilihat dalam nilai-nilai $r$ 
Product Moment, $\mathrm{r}$ tabel $=-0,3$. Jika $\mathrm{r}$ hitung $>\mathrm{r}$ tabel maka item tersebut dinyatakan valid, dan jika $r$ hitung $<\mathrm{r}$ tabel maka item tersebut dinyatakan tidak valid.

\section{Uji Reliabilitas}

Uji reliabilitas digunakan untuk mengetaui ketetapan suatu instrumen (alat ukur) dalam mengukur gejala yang sama walaupun pada waktu yang berbeda. Dalam Sugiyono (2014:348) menyebutkan bahwa reliablitas instrumen adalah suatu instrumen yang bila digunakan beberapa kali untuk mengukur objek yang sama, maka akan menghasilkan data yang sama. Hasil pengukuran yang memiliki tingkat reliabilitas yang tinggi akan mampu memberikan hasil yang terpercaya. Dalam perhitungan SPSS untuk menentukan nilai reliabilitas data adalah dari nilai Cronbach's Alpha. Menurut Nunnaly (2002) suatu "construct" dianggap reliabel jika koefisien alphanya >0,60 (Ghozali, 2012:47).

\section{Metode Analisis Data Uji Asumsi Klasik}

\section{- Uji Normalitas}

Uji normalitas merupakan salah satu bagian dari uji persyaratan analisis data atau uji asumsi klasik, artinya sebelum kita melakukan analisis yang sesungguhnya, data penelitian tersebut harus diuji konormalan distribusinya. Dasar keputusan dari uji normalitas adalah jika nilai signifikansi lebih besar dari 0,05 maka data tersebut berdisitirbusi normal. Sebaliknya, jika nilai signifikansi lebih kecil dari 0,05 maka data tersebut tidak berdistribusi normal. Cara melakukan uji normalitas adalah menggunakan uji Kolmogorov-Smirnov dengan asumsi nilai Asymp Sig (2-tailed) > 0,05 , sehingga dapat disimpulkan data yang diuji berdistribusi normal.

\section{- Uji Multikolinearitas}

Uji Multikolinearitas bertujuan untuk menjguji apakah suatu model regresi terdapat korelasi antar variabel bebas (independen). Modal regresi yang baik seharusnya tidak terjadi korelasi antar variabel independen. Pengujian multikolinearitas dilihat dari besaran VIF (Variance Inflation Factor) dan Tolerance. Tolerance berguna untuk mengukur variabel independen yang terpilih yang tidak dijelaskan oleh variabel independen lainnya. Jadi nilai tolerance yang rendah sama dengan nilai VIF tinggi (karena VIF= I/tolerance). Nilai cutoff yang umum dipakai untuk menunjukkan adanya multikolinearitas adalah nilai tolerance $>0,01$ atau sama dengan nilai VIF $<10$ (Ghozali 2012:105).

- Uji Heteroskedastisitas

Dalam Ghozali (2012:139) disebutkan bahwa uji heterokedastisitas bertujuan untuk menguji apakah dalam model regresi terjadi ketidaksamaan varian dari residual satu pengamatan ke pengamatan yang lain. Jika varian dari residual satu pengamatan ke pengamatan lain tetap, maka disebut homoskedastisitas dan jika berbeda disebut heteroskedastisitas. Untuk mengetahui terjadi heteroskedastisitas atau tidak adalah dengan melihat Grafik Plot antara nilai prediksi variabel dependen yaitu ZPRED dengan residual SRESID. Dinyatakan tidak terjadi heteroskedastisitas apabila tidak pada pola yang jelas, serta titik-titik menyebar di atas dan di bawah angka 0 pada sumbu $Y$.

\section{Uji Regresi Linier Berganda}

Uji regresi linier berganda adalah hubungan secara linier antara dua atau lebih variabel independen yaitu: Motivasi Berwirausaha (X1), Mental Berwirausaha 
(X2) terhadap variabel terikatnya yaitu Minat Berwirausaha (Y). Uji ini untuk mengetahui arah hubungan antara variabel independen dengan variabel dependen apakah masing-masing berhubungan positif atau negative dan untuk memprediksi nilai dari variabel dependen apabila nilai variabel independen mengalami kenaikan atau penurunan. Persamaan regresi linier berganda adalah sebagai berikut (Ghozali, 2005): $Y=a+$ b1X1 + b2X2

Dimana:

$\mathrm{Y}=$ Variabel dependen (Minat Berwirausaha)

$\mathrm{a}=$ Konstanta

b1, b2, = Koefisien regresi

$\mathrm{X} 1, \mathrm{X} 2,=$ Variabel independen (Motivasi Berwirausaha dan Mental Berwirausaha)

\section{Uji Koefisien Determinasi $\left(R^{2}\right)$}

Koefisien determinasi $\left(R^{2}\right)$ bertujuan untuk mengukur seberapa jauh kemampuan model dalam menerangkan variasi variabel dependen. Nilai koefisien determinasi adalah antara nol atau satu. Dalam Ghozali (2012) disebutkan bahwa terdapat kelemahan dalam uji koefisien deteraminasi/R Square sehingga banyak peneliti menganjurkan untuk mengunakan nilai Adjusted $\mathrm{R}$ Square, karena nilai Adjusted R Square akan berubah apabila terdapat tambahan variabel independen yang bersifat irrelevance.

\section{Uji Hipotesis}

Pengujian hipotesis adalah suatu prosedur yang akan menghasilkan suatu keputusan, yaitu keputusan menerima dan menolak hipotesis tersebut. Hipotesis merupakan bagian penting dalam suatu penelitian, karena dengan adanya hipotesis penelitian menjadi lebih terarah. Uji hipotesis harus diuji kebenarannya melalui uji statistik. Pengujian hipotesis dalam penelitian ini menggunakan:

a. Uji t (Parsial)

Uji beda t-test digunakan untuk menguji seberapa jauh pengaruh variabel independen yang digunakan dalam penelitian ini secara individual dalam menerangkan variabel dependen secara parsial. Dasar pengambilan keputusan digunakan dalam uji t adalah sebagai berikut:

- Jika nilai probabilitas signifikansi $>0,05$, maka hipotesis ditolak, artinya variabel independen tidak berpengaruh signifikan terhadap variabel dependen.

- Jika nilai probabilitas signifikansi $<0,05$, maka hipotesis diterima, artinya variabel independen berpengaruh signifikan terhadap variabel dependen.

b. Uji F (Simultan)

Uji $F$ digunakan untuk menguji kebenaran antara variabel-variabel independen terhadap variabel dependen yang terdapat dalam model regresi. Analisis uji F ini dilakukan dengan membandingkan antara $\mathrm{F}$ hitung dengan $F$ tabel. Sebelum membandingkan nilai $\mathrm{f}$ tersebut, juga harus ditentukan tingkat kepercayaan 95\%. Jika F hitung $>\mathrm{F}$ tabel atau $\mathrm{P}$ value $>\alpha$, disebut tidak signifikan, sebaliknya jika $\mathrm{F}$ hitung < F tabel atau $P$ value $>\alpha$ disebut signifikan..

\section{HASIL PENELITIAN DAN PEMBAHASAN \\ Pengujian Validitas dan Reliabilitas Instrumen \\ Uji Validitas Instrumen}

Pengujian validitas dilakukan dengan program SPSS dengan pengambilan keputusan berdasarkan nilai Corrected Item-Total Correlation $>0,3$, maka 
item/pertanyaan tersebut disebut valid dan sebaliknya. Seluruh pertanyaan untuk variabel (Motivasi Berwirausaha, Mental Berwirausaha, dan Minat Berwirausaha) memiliki koefisien validitas, karena nilai Corrected Item-Total Correlation $>0,3$, sehingga item-item tersebut layak digunakan sebagai alat ukur penelitian.

\section{Uji Reliabilitas Instrumen}

Uji Reliabilitas dilakukan terhadap item pertanyaan yang dinyatakan valid. Uji reliabilitas dengan menggunakan rumus Cronbach Alpha dan hasil yang diperoleh menunjukan nilai Cronbach Alpha untuk variabel (Motivasi Berwirausaha, Mental Berwirausaha dan Minat Berwirausaha) > 0,60 , artinya ketiga variabel independen dinyatakan reliabel atau memenuhi persayaratan.

\section{Uji Asumsi Klasik \\ Uji Normalitas}

Uji normalitas pada penelitian ini menggunakan uji Kolmogorov Smirnov yang menyatakan bahwa apabila nilai Asymp.Sig (2-tailed) lebih besar dari 0,05, maka data terdistribusi normal. Hasil uji Kolmogorov Smirnov adalah sebagai berikut:

\section{Tabel 2}

One-Sample Kolmogorov-Smirnov Test

\begin{tabular}{|l|l|r|r|r|}
\hline \multicolumn{7}{|c|}{ One-Sample Kolmogorov-Smirnov Test } \\
\hline & \multicolumn{1}{|c|}{$\begin{array}{c}\text { Motivasi } \\
\text { Berwirausaha }\end{array}$} & $\begin{array}{c}\text { Mental } \\
\text { Berwirausaha }\end{array}$ & $\begin{array}{c}\text { Minat } \\
\text { Berwirausaha }\end{array}$ \\
\hline $\mathrm{N}$ & 40 & 40 & 40 \\
\hline \multirow{2}{*}{$\begin{array}{l}\text { Normal } \\
\text { Parameters }\end{array}$} & Mean & 38.22 & 36.32 & 39.75 \\
\cline { 2 - 6 } & Std. Deviation & 4.359 & 4.221 & 3.600 \\
\hline Most & Absolute & .208 & .123 & .178 \\
\cline { 2 - 6 } $\begin{array}{l}\text { Extreme } \\
\text { Differences }\end{array}$ & Positive & .145 & .123 & .119 \\
\cline { 2 - 6 } & Negative & -.208 & -.111 & -.178 \\
\hline Kolmogorov-Smirnov Z & 1.316 & .779 & 1.124 \\
\hline Asymp. Sig. (2-tailed) & .063 & .578 & .160 \\
\hline a. Test distribution is Normal. & & & & \\
\hline
\end{tabular}

Sumber: Hasil Output SPSS 16

Pada tabel 1 menunjukkan bahwa nilai Asymp.Sig (2-tailed) sebesar 0,063 (X1), 0,578 (X2) dan 0,160 (Y)>0,05. Berdasarkan hasil ini dapat dinyatakan bahwa data yang digunakan dalam penelitian ini berdistribusi normal.

\section{Uji Multikoliniearitas}

Uji multikolinieritas digunakan untuk menguji apakah model regresi ditemukan adanya korelasi antar variabel independen. Untuk mengatahui ada tidaknya penyimpangan uji multikolinieritas adalah dengan melihat nilai Tolerance dan Variace Inflation Factor (VIF) masing-masing variabel independen. jika nilai Tolerance $>0,10$ dan nilai $\mathrm{VIF}<10$, maka data bebas dari gejala multikolinieritas. Hasil pengujian dapat diketahui sebagai berikut:

Tabel 3

Nilai VIF

\begin{tabular}{|c|l|r|r|}
\hline \multicolumn{2}{|c|}{ Model } & \multicolumn{2}{c|}{ Collinearity Statistics } \\
\cline { 3 - 4 } \multicolumn{2}{|c|}{1} & Tolerance & \multicolumn{1}{c|}{ VIF } \\
\hline \multirow{3}{*}{1} & (Constant) & & \\
\cline { 2 - 4 } & Motivasi Berwirausaha & .666 & 1.502 \\
\cline { 2 - 4 } & Mental Berwirausaha & .666 & 1.502 \\
\hline
\end{tabular}

Sumber: SPSS

Pada tabel di atas dapat diketahui bahwa nilai Tolerance masing-masing variabel indenpenden adalah sebesar 0,666>10\% dan Variance Inflation Factor (VIF) untuk masing-masing variabel independen $1,502<\mathrm{VIF}=10$, maka dapat disimpulkan bahwa antara variabel independen tidak terjadi multikolinieritas.

\section{Uji Heteroskedastisitas}

Uji Heteroskedastisitas bertujuan untuk menguji apakah dalam model regresi terjadi ketidaksamaan varians dari residual satu pengamatan ke pengamatan yang lain. Hasil pengujiannya dalam grafik diketahui bahwa tidak ada pola yang jelas dan titik-titik menyebar di bawah serta di atas sumbu Y. Hal ini menunjukkan bahwa variabel independen tidak terjadi heteroskedastisitas.

\section{Uji Regresi Linier Berganda}

Analisis regresi linear berganda digunakan untuk mengukur pengaruh 
antara lebih dari satu variabel prediktor (variabel bebas) terhadap variabel terikat.

Hasil pengujian yang dilakukan dapat dilihat pada tabel berikut:

Tabel 4

Uji Regresi Linier Berganda

\begin{tabular}{|c|c|c|c|c|c|c|}
\hline \multirow{2}{*}{\multicolumn{2}{|c|}{ Model }} & \multicolumn{2}{|c|}{$\begin{array}{l}\text { Unstandardized } \\
\text { Coefficients }\end{array}$} & \multirow{2}{*}{\begin{tabular}{c|}
$\begin{array}{c}\text { Standardized } \\
\text { Coefficients }\end{array}$ \\
Beta \\
\end{tabular}} & \multirow[b]{2}{*}{$\mathrm{t}$} & \multirow[b]{2}{*}{ Sig. } \\
\hline & & B & Std. Error & & & \\
\hline \multirow[t]{3}{*}{1} & (Constant) & $\begin{array}{r}10.78 \\
4\end{array}$ & 3.845 & & 2.805 & .008 \\
\hline & \begin{tabular}{|l|} 
Motivasi \\
Berwirausaha
\end{tabular} & .360 & .108 & .424 & 3.323 & .002 \\
\hline & Mental Berwirausaha & .394 & .113 & .447 & 3.501 & .001 \\
\hline & ependent Variable: Mi & Berw & irausaha & & & \\
\hline
\end{tabular}

Sumber: data diolah SPSS

Tabel di atas menunjukkan model persamaan regresi linier ganda yang dibentuk berdasarkan hasil perhitungan adalah $\hat{Y}=10,784+0,360 \times 1+0,394 X 2$, artinya adalah:

- $\quad$ Konstanta a $=10,784$, artinya jika tidak ada Motivasi Berwirausaha (X1) dan Mental Berwirausaha (X2), maka Minat Berwirausaha (Y)sebesar 10,784 .

- Koefisien Regresi Motivasi Berwirausaha (X1) sebesar 0,360 artinya setiap kenaikan satu satuan pada Motivasi Berwirausaha (X1) akan meningkatkan Minat Berwirausaha sebesar 0,360.

- Koefisien Regresi Mental Berwirausaha (X2) sebesar 0,394 artinya setiap kenaikan satu satuan pada Mental Berwirausaha (X2) akan meningkatkan Minat Berwirausaha sebesar 0,394.

\section{Uji Hipotesis}

Uji hipotesis dalam penelitian ini menggunakan uji $t$ dan uji $F$. Uji $t$ digunakan untuk membuktikan pengaruh secara parsial variabel independen terhadap variabel dependen, dan uji F digunakan untuk membuktikan pengaruh secara serentak variabel independen terhadap variabel dependen.

\section{Uji $t$} berikut:

Hasil uji $t$ dapat dilihat pada tabel Tabel 5

Uji Hipotesis

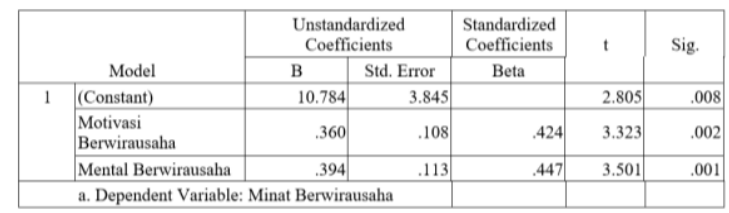

Sumber: data diolah SPSS

Tabel di atas menunjukkan bahwa variabel indevenden Motivasi Berwirausaha $(X 1)$ diperoleh nilai $\mathrm{t}$ hitung sebesar 3,323 dengan probabilitas sig sebesar 0,002 yang nilai di bawah 0,05 sehingga Ha diterima yang artinya bahwa terdapat pengaruh positif signifikan Motivasi Berwirausaha (X1) terhadap Minat Berwirausaha $(Y)$.

Hasil uji $t$ menunjukkan bahwa variabel indevenden Mental Berwirausaha (X1) diperoleh nilai t hitung sebesar 3,501 dengan probabilitas sig sebesar 0,001 yang nilai di bawah 0,05 sehingga Ha diterima yang artinya bahwa terdapat pengaruh positif signifikan Mental Berwirausaha (X1) terhadap Minat Berwirausaha (Y).

\section{Uji F}

Hasil uji F dapat dilihat pada tabel berikut:

Tabel 6

ANOVA

\begin{tabular}{|c|c|c|c|c|c|c|}
\hline \multicolumn{7}{|c|}{ ANOVA $^{b}$} \\
\hline \multicolumn{2}{|r|}{ Model } & $\begin{array}{l}\text { Sum of } \\
\text { Squares }\end{array}$ & df & Mean Square & $\mathrm{F}$ & Sig. \\
\hline \multirow[t]{3}{*}{1} & Regression & 342.678 & 2 & 171.339 & 27.597 & $.000^{\circ}$ \\
\hline & Residual & 229.722 & 37 & 6.209 & & \\
\hline & Total & 572.400 & 39 & & & \\
\hline
\end{tabular}

Berdasarkan tabel Anova di atas, diketahui bahwa nilai $\mathrm{F}$ hitung sebesar 27,597 dengan nilai probabiltas sig sebesar 0,000 yang dinilainya di bawah 0,05 . Hal ini menunjukkan bahwa semua variabel independen yaitu Motivasi Berwirausaha (X1) dan Mental Berwirausaha (X2) 
berpengaruh signifikan secara simultan (bersama-sama) terhadap Minat Berwirausaha (Y) yang artinya $\mathrm{Ha}$ diterima.

\section{Uji Koefisien Determinasi}

Dari hasil pengujian yang dilakukan sebagai berikut:

\section{Tabel 7}

Uji Koefisien Determinasi

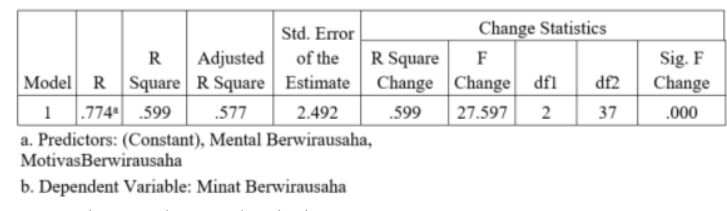

Sumber: data diolah SPSS

Dari tabel Koefisien Determinasi di atas dapat dilihat bahwa nilai $R=0,774$ dan koefisien determinasi yang disesuaikan atau Adjusted R Square = 0,577 atau 57,7\% sehingga dapat diinterpretasikan bahwa Motivasi Berwirausaha dan Mental Berwirausaha secara bersama-sama mempengaruhi Minat Berwirausaha sebesar $\quad 57,7 \%$ sedangkan $\quad 42,3 \% \quad(100-$ $57,7 \%$ ) diterangkan oleh faktor lain.

\section{KESIMPULAN}

a. Motivasi berwirausaha berpengaruh positif dan signifikan terhadap minat berwirausaha. Sehingga dapat dikatakan bahwa semakin tinggi motivasi berwirausaha yang dimiliki oleh para mahasiswa Program Studi S1 Manajemen STIE IPWI Jakarta maka minat berwirausahanya juga akan semakin tinggi.

b. Mental berwirausaha berpengaruh positif dan signifikan terhadap minat berwirausaha. Sehingga dapat dikatakan bahwa semakin kuat mental berwirausaha pada diri para mahasiswa Program Studi S1 Manajemen STIE IPWI Jakarta maka minat berwirausahanya juga akan semakin kuat.

c. Secara bersama-sama motivasi berwirausaha dan mental berwirausaha berpengaruh positif dan signifikan terhadap minat berwirausaha, semakin meningkat motivasi berwirausaha dan mental berwirausaha maka minat berwirausaha para mahasiswa Program Studi S1 Manajemen STIE IPWI Jakarta akan semakin meningkat.

\section{SARAN}

Saran yang dapat peneliti sampaikan adalah:

a. Bahwa motivasi berwirausaha yang telah dimiliki oleh para mahasiswa Program Studi S1 Manajemen STIE IPWI Jakarta harus ditingkatkan khususnya dalam memberikan dorongan untuk menggerakkan semangat serta mamberikan arahan untuk tetap bersemangat dalam membentuk jiwa berwirausaha.

b. Mental berwirausaha yang dimiliki oleh para mahasiswa Program Studi S1 Manajemen STIE IPWI Jakarta harus tetap menjadi prioritas utama untuk dikembangkan sehingga mereka mempunyai jiwa yang besar, penuh semangat dan optimis terhadap tujuan yang ingin dicapai dalam mengembangkan jiwa wirausaha. Dengan mental berwirausaha yang kuat tentu akan mencetak individu yang mampu melihat peluangpeluang bisnis yang sehingga tercetak para wirausahawan-wirausahawan muda yang penuh inovatif dan penuh kreativitas.

c. Minat berwirausaha pada mahasiswa dapat ditumbuhkan dengan memberikan pembekalan pendidikan kewirausahan untuk karakter 
kepribadian yang kuat, percaya diri, berani mengambil resiko, mandiri dan mempunyai jiwa wirausahawan sejati.

\section{DAFTAR PUSTAKA}

Agustina, Tri Siswi. (2015). Kewirausahaan: Teori dan Penerapan pada Wirausaha dan UKM di Indonesia. Jakarta: Mitra Wacana Media

Alifuddin, Moh dan Mashur Razak. (2015). Kewirausahaan Teori dan Aplikasi, Strategi Membangun Kerajaan Bisnis. Jakarta: MagnaScript Publishing

Almar, Buchori. (2014). Kewirausahaan, Bandung: Alfabeta

Anoraga, Pandji. (2011). Pengantar Bisnis. Jakarta: Rineka Cipta

Basrowi. (2016). Kewirausahaan untuk Mahasiswa dan Umum. Bandung: Alfabeta

Darmanto. (2001). Enterpreneurship dalam Perguruan Tinggi. Yogyakarta: Dafiri

Dharmawati, D. Made. (2016). Kewirausahaan. Cetakan ke-1. Depok: PT Rajagrafindo Persada

Direktorat Jenderal Pembelajaran \& Kemahasiswaan Kementerian Riset, Teknologi dan Pendidikan Tinggi. (2015). Pedoman Program Mahasiswa Wirausaha (PMW). Jakarta: Dikti

Djaali. (2008). Psikologi Pendidikan. Jakarta: Bumi Aksara

Fadiati, Ari. Dedi Punwana. (2011). Menjadi Wirausaha Sukses. Cetakan kedua. Bandung: PT Remaja Rosdakarya

Garjito. (2014.) Kewirausahaan. Yogyakarta: Akmal Publishing Ghozali, Imam. (2012). Aplikasi Analisis Multivariate dengan Program
SPSS Edisi Keempat. Semarang: Undip

Hasibuan. Malayu SP. (2010). Manajemen Sumber Daya Manusia, Jakarta: Bumi Aksara Indrawan, Rully. (2014). Metodologi Penelitian Kualitatif, Kuantitatif dan Campuran. Surabaya: Refika Aditama

Kasali, Renald dkk, (2012). Kewirausahaan. Jakarta: Hikmah

Kasmir. (2012). Kewirausahaan (edisi revisi) Jakarta: Rineka Cipta

Robbin, Stephen P. Mary Coulter. (2007). Manajemen. Edisi Kedelapan Jilid 2. PT Indek.

Saiman, Leonardus, (2014). Kewirausahaan: Teori, Praktik dan Kasus-kasus Edisi 2, Jakarta: Salemba Empat

Singgih Santoso, 2008. SPSS Statistik Multivariat. Jakarta. PT Alez Media Komputindo

Sugiyono. 2015. Metode Penelitian dan Pengembangan (Research and Development). Cetakan ke-1. Bandung. CV Alfabeta

Suharsimi, Arikunto, (2013). Prosedur Penelitian suatu Pendekatan Praktis. Jakarta: Rineka Cipta

Sujarweni, V. Wiratna. (2015). Metodologi Penelitian Bisnis dan Ekonomi. Cetakan ke-1. Yogyakarta: Pustakabarupress

Suryana, (2017). Kewirausahaan Pedoman Praktis: Kiat dan Proses Menuju Sukses. Bandung: Salemba 4

Widyaning, Yunita. (2014). Pengaruh Pendidikan Kewirausahaan terhadap Motivasi Berwirausaha dan Keterampilan Berwirausaha Mahasiswa Pendidikan Ekonomi Universitas Negeri Yogyakarta. Yogyakarta: Fakultas Ekonomi. UNY 